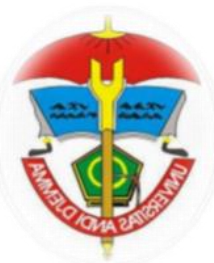

\author{
Tugas Akhir \\ Prodi Manajemen Fakultas Ekonomi \\ Universitas Andi Djemma Palopo
}

\title{
Pengaruh Disiplin Kerja dan Pelatihan Terhadap Kinerja Karyawan Pada PT. Kumala Motor Sejahtera Kota Palopo
}

\begin{abstract}
Wahdania
(Program Studi Manajemen Fakultas Ekonomi Universitas Andi Djemma Palopo,

Email: wahdaniaramadahani@gmail.com)
\end{abstract}

Pembimbing: Didi Haryono, S.Si., M. Si \& Khaerana, S.E., M. M

\section{Abstrak}

Penelitian ini bertujuan untuk mengetahui variabel pengaruh Disiplin kerja dan Pelatihan Terhadap Kinerja Karyawan Pada PT. Kumala Motor Sejahtera Kota Palopo. Hasil analisis data dengan menggunakan bantuan program statistik SPSS diperoleh persamaan regresi linear berganda sebagai berikut: $Y=6.246+0.756 X 1$ $+0.066 \mathrm{X}_{2}+\mathrm{e}$, artinya apabila nilai variabel Disiplin Kerja dan Pelatihan nilainya sama dengan nol atau dalam keadaan Konstan, maka nilai varaiabel Kinerja Karyawan pada PT. Kumala Motor Sejahtera Kota Palopo sebesar 6.246. Jika nilai koefisien regresi untuk variabel Disiplin kerja sebesar 0.756, artinya bahwa apabila Disiplin Kerja ditingkatkan sebesar satu satuan maka akan mempengaruhi Kinerja Karyawan pada PT. Kumala Motor Sejahtera Kota Palopo dan jika nilai koefisien regresi untuk variabel pelatihan finansial sebesar 0.066, artinya bahwa apabila variabel pelatihan menurun sebesar satu satuan maka akan mempengaruhi Kinerja Karyawan pada PT. Kumala Motor Sejahtera Kota Palopo sebesar 0.066 satuan. Dari hasil analisis koefisien determinasi, diketahui bahwa nilai koefisien determinasi (R Square) sebesar 0.522. Hal ini berarti variabel Disiplin Kerja dan Pelatihan berpengaruh sebesar 52,2\% terdapat peningkatan variabel Kinerja Karyawan pada PT.Kumala Motor Sejahtera Kota Palopo sedangkan sisanya sebanyak 47,8\% dipengaruhi oleh faktor lain yang tidak diteliti dalam penelitin ini. Hasil pengujian parsial untuk variabel Disiplin Kerja, nilai Thitung (4.266) > Ttabel (2.086) dan tingkat signifikansi sebesar $0.000<0.005$, maka dapat disimpulkan bahwa Disiplin Kerja secara parsial berpengaruh signifikan terhadap Kinerja Karyawan pada PT. Kumala Motor Sejahtera Kota Palopo dan untuk variabel Pelatihan menunjukkan nilai Thitung $(0.526)<$ Ttabel (2.086) Dan signikansi sebesar $0.675>0.005$, maka dapat disimpulkan bahwa Pelatihan secara parsial tidak berpengaruh signifikan terhadap Kinerja Karyawan pada PT. Kumala Motor Sejahtera Kota Palopo. Nilai Fhitung (10.916) > (3.49) dan signifikansi sebesar 0.001 $<0.05$, maka dapat disimpulkan bahwa Disiplin Kerja dan Pelatihan secara simultan 
berpengaruh signifikan terhadap Kinerja Karyawa pada PT. Kumala Motor Sejahtera Kota Palopo.

Kata kunci: Disiplin Kerja, pelatihan dan Kinerja Karyawan.

\section{Pendahuluan}

Potensi Sumber Daya Manusia pada dasarnya merupakan salah satu modal dan memegang peran yang paling penting dalam mencapai tujuan perusahaan. Oleh karena itu, perusahaan perlu mengelola Sumber Daya Manusia sebaik mungkin, sebab kunci sukses suatu perusahaan bukan hanya pada keunggulan teknologi dan tersedianya dana saja akan tetapi di pengaruhi oleh faktor manusia. Faktor manusia merupakan faktor yang terpenting, manusia bisa dikatakan sebagai sumber daya utama yang mampu mengatur, menganalisis, dan mengendalikan masalah yang ada di dalam perusahaan. Selain itu manusia mempunyai keinginan, pikiran, perasaan, status dan latar belakang yang beragam yang dibawa ke dalam perusahaan untuk mencapai tujuan yang diinginkan perusahaan.Perusahaan dituntut memiliki pandangan dan sikap disiplin untuk meningkatkan produktivitas pegawai, demi mencapai tujuan yang diinginkan (Suti dkk, 2021). Disiplin kerja merupakan fungsi manajemen sumber daya manusia terpenting dan berkaitan erat dengan pengelolaan sumber daya bagi suatu perusahaan (Khaerana \& Olfiyandari, 2019). Pada dasarnya setiap pegawai menyadari bahwa disiplin kerja merupakan kunci keberhasilan yang harus diterapkan dan harus dilaksanakan oleh masing-masing individu karena dengan displin kerja yang baik akan memberikan kelancaran dalam proses menjalankan pekerjaan dan juga akan mencapai hasil kerja yang maksimal dalam perusahaan.

Penting bagi perusahaan mengetahui kinerja karyawan, melalui kinerja dapat melihat seberapa jauh kemampuan pegawai dalam melaksanakan tugas yang yang dibebankan kepadanya (Sinambela, 2012:38). Terdapat beberapa ciri yang memberikan pengaruh terhadap kinerja seseorang, menurut Robbins dan Judge (2013:83) tingkat kinerja karyawan bergantung pada kemampuan yang ada didalam karyawan itu sendiri seperti pelatihan, pengetahuan dan disiplin, apabila kemampuan karyawan semakin baik maka kinerja juga akan semakin mengalami peningkatan. Selain itu, Mangkuprawira dan Hubeis (2007:62) juga berpendapat 
bahwa kinerja karyawan dapat ditentukan oleh beberapa faktor yaitu: faktor personal yang meliputi keterampilan, kepercayaan diri, disiplin, dan komitmen yang dimiliki oleh setiap individu karyawan: faktor kepemimpinan yang meliputi aspek kualitas pemimpin dalam memberi dorongan dan dukungan kerja kepada karyawan faktor tim yang meliputi dukungan kerja dari kolega kerja, kekompakan dan keeratan anggota tim:faktor sitem yang meliputi sistem kerja ialah fasilitas kerja, proses organisasi, pelatihan untuk kesempatan berkarir dan kultur kinerja dalam organisasi dan faktor kontekstual (Suti dkk, 2020). Salah satu faktor penting yang mempengaruhi kinerja karyawan adalah kedisiplinan, melalui yang disampaikan Sisnambela (2012:48) mengatakan disiplin kerja dapat mempengaruhi kinerja, terbukti dari semakin tinggi disiplin seseorang karyawan maka semakin tinggi juga kinerja orang tersebut. Selain itu faktor penting lainnya yaitu kegiatan pelatihan kerja karyawan, untuk membantu karyawan mengembangkan kapasitas atau pengetahuan yang dimilikinya sehingga karyawan dapat bekerja lebih baik dan meningkatkan kinerja demi tercapainya tujuan perusahaan dimasa yang akan datang (Kartika \& Khaerana, 2019).

Disiplin kerja merupakan suatu alat peringatan yang penting diterapkan diperusahaan untuk membantu meningkatkan kinerja karyawan. Dengan meningkatkan kinerja maka tujuan perusahaan yang diharapkan akan lebih optimal untuk dicapai. Hasil penelitian yang dilakukan Pangarso dan Susanti (2015) dalam (Kartikasari \& Djastuti, 2017:3) mengatakan bahwa disiplin kerja harus dibudidayakan dikalangan karyawan agar bisa mendukung tercapainya tujuan organisasi karena merupakan wujud dari kepatuhan terhadap aturan kerja dan juga sebagai tanggung jawab terhadap prusahaan. Disiplin kerja yang baik yakni mencereminkan besarnya rasa tanggung jawab seorang karyawan terhadap tugastugas yang diberikan kepadanya, Hal tersebut dapat mendorong timbulnya peningkatan kerja serta tercapainya tujuan perusahaan. Oleh karena itu yang diterapkan dengan baik akan menghasilkan kinerja karyawan yang baik, sebaliknya apabila disiplin kerja yang diterapkan kurang baik maka akan menghasilkan kinerja karyawan yang kurang baik pula. 
Pelatihan merupakan salah satu komponen penting dalam pengembangan sumber daya manusia (SDM) pada sebuah instinsi. Penyelenggaraan program pelatihan diharapkan dapat meningkatkan pengetahuan, keterampilan, dan sikap positif SDM yang merupakan asset penting dalam institusi. Peringkat pengetahuan, keterampilan, dan sikap akibat pelaksanaan program pelatihan diharapkan dapat meningkatkan kinerja institusi dalam menghadapi perubahan dan persaingan eksternal (Benny, 2016:1).

PT. kumala motor sejahtera kota palopo merupakan perusahaan yang beroperasi pada bidang penjualan dan pengembangan sumber daya manusia. Dimana terdapat dua output yang dihasilkan perusahaan tersebut. Output pertama yaitu berupa jasa pelatihan bagi isntansi maupun individu yang membutuhkan sesuai dengan bidang yang ingin didalami dimana pengguna teknologi digital juga dilibatkan dalam prosesnya, dan output kedua yang berupa produk otomotif, digunakan untuk perusahaan yang ingin sumber daya manusianya terorganisir dengan baik dimulai dari absensi karyawan, penggaji karyawan, pengajuan cuti, dan pengajuan klaim dengan mudah dan cepat hanya dengan produk yang ditawarkan. Perusahaan ini memiliki tiga model konsumen, para Ahli, penyewa, dan Pengguna biasa. Ketiga konsumen ini tentunya memiliki kebutuhan yang berbeda-beda. Untuk itu para karyawan PT. kumala motor sejahtera kota palopo harus memberi pelayanan maksimal untuk melayani konsumen-konsumen. Namun sering kali kinerja karyawan karyawan tidak berjalan dengan baik, tentunya dalam bidang pekerjaan seperti ini dibutuhkan kinerja yang baik agar tidak meninggalkan kekecewaan dari konsumennya. Kinerja yang tidak baik dapat dilihat dari lalainya tugas-tugas yang diberi, tidak selesai tepat waktu. Dan juga sering sekali hasil kerja karyawan tidak melampaui keinginan konsumen, dapat dikatakan bahwa sering terjadi adanya missed communication antara karyawan dengan konsumen.

Ketidak disiplinan karyawan membuat segala pekerjaan menjadi terhambat. Konsumen sering mengelukan pekerjaan yang tidak kunjung selesai dan banyaknya revisi. Hal tersebut tentu berpengaruh dengan kecepatan dalam menyelesaikan pekerjaanya. Selain itu minimnya penguasaan bidang yang dimiliki karyawan juga menyebabkan kinerja karyawan yang kurang baik. Pelatihan kerja yang disediakan 
perusahaan tidak secara maksimal memberikan dampak besar untuk kinerja karyawan. Padahal pelatihan kerja yang baik sangat dibutuhkan karena disamping itu karyawan yang berada didalam perusahaan ini memiliki perbedaan antara latar Pendidikan dengan pekerjaan yang dimiliki saat ini. Seperti pada contoh karyawan pada divisi pemasaran yang dahulunya mendalami disiplin ilmu yang berbanding jauh. Perbedaan latar belakang Pendidikan dan meminimnya pengalaman harus menjadi landasan kuat bagi perusahaan menciptakan pelatihan kerja yang optimal untuk karyawannya, demi tercapainya tujuan kinerja yang baik didalam perusahaan.

Dari Observasi diawal yang dilakukan terlihat permasalahan pada PT. Kumala Motor Sejahtera Kota Palopo masih ditemui kinerja karyawan yang kurang sesuai dengan keinginan atasan, hal ini terlihat dari adanya beberapa karyawan yang melakukan kesalahan- kesalahan kerja selain itu Masih kurang disiplin kerja seperti karyawan kurang memiliki tanggung jawab dengan penuh karena banyak karyawan yang telat masuk setelah jam istirahat, menunda-nunda pekerjaan yang diberikan oleh pimpinan mereka dalam artian Ketika pimpinan tidak berada ditempat, maka kebanyakan karyawan menghabiskan waktunya untuk bercerita dan bercanda ini sangat mempengaruhi lancarnya operasional dalam perusahaan. Adapun pelatihan yang diberikan tidak merata kesemua karyawan dan hanya orang-orang terpilih dan kerabat terdekat saja yang mendapat pelatihan.

\section{Metode}

Penelitian ini dilaksanakan pada PT. Kumala Motor Sejahtera Kota Palopo J1. Andi Djemma (depan polsek wara), Binturu, Wara Selatan Kota Palopo. Waktu yang dibutuhkan selama 3 bulan yaitu Juni sampai Agustus 2021. Teknik analisis yang digunakan dalam penelitian ini adalah menggunakan Analisis Regresi Linear Berganda. Regresi linear linear berganda dilakukan terhadap dua atau lebih variabel bebas, untuk diketahui pengaruhnya terhadap variabel terikat (Santoso, 2010). Pada penelitian ini menggunakan alat bantu program statistik SPSS for windows untuk mempermudah proses pengolahan data-data penelitian dari program tersebut akan didapatkan output berupa hasil pengolahan dari data yang telah dikumpulkan, kemudian output hasil pengolahan data tersebut diinterprestasikan dan akan 
dilakukan analisis terhadapnya, kemudian diambil sebuah kesimpulan sebagai sebuah hasil dari penelitian.

Regresi linear berganda dilakukan untuk mengetahui sejauh mana variabel bebas mempengaruhi variabel terikat. Dalam penelitian ini yang menjadi variabel terikat adalah kinerja karyawan, sedangkan yang menjadi variabel bebas adalah disiplin kerja dan pelatihan. Model hubungan kinerja karyawan dengan variabel tersebut dapat disusun dalam fungsi atau persamaan sebagai berikut:

$$
\mathrm{Y}=\mathrm{a}+\mathrm{b}_{1} \mathrm{X}_{1}+\mathrm{b}_{2} \mathrm{X}_{2}+\mathrm{e} \text {. }
$$

Keterangan:

$$
\begin{array}{ll}
\mathrm{Y} & =\text { Kinerja karyawan } \\
\mathrm{X}_{1} & =\text { Disiplin kerja } \\
\mathrm{X}_{2} & =\text { Pelatihan } \\
\mathrm{a} & =\text { Konstanta } \\
\mathrm{b}_{1} & =\text { Koefisien regresi variable } \mathrm{X}_{1} \\
\mathrm{~b}_{2} & =\text { Koefisien regresi variable } \mathrm{X}_{2} \\
\mathrm{e} & =\text { Variabel pengganggu (error term) }
\end{array}
$$

\subsection{Hasil Penelitian}

\section{Hasil dan Pembahasan}

Berikut ini disajikan hasil penelitian Pengaruh Disiplin Kerja dan Pelatihan

\begin{tabular}{|c|c|c|c|c|c|c|}
\hline & & \multicolumn{5}{|c|}{ ANOVA $^{a}$} \\
\hline \multicolumn{2}{|c|}{ Model } & Sum of Squares & Df & Mean Square & $\mathrm{F}$ & Sig. \\
\hline & Regression & 132.429 & 2 & 66.214 & 10.916 & $.001^{\mathrm{b}}$ \\
\hline & Residual & 121.311 & 20 & 6.066 & & \\
\hline & TOTAL & 253.739 & 22 & & & \\
\hline
\end{tabular}
Terhadap Kinerja karyawan pada PT. Kumala Motor Sejahtera Kota Palopo Menggunakan Uji analisis Regresi Berganda sebagai berikut:

\section{a. Uji F (Simultan)}

Pengujian hipotesis dilakukan secara bersama-sama untuk mengetahui pengaruh variabel bebas yaitu Disiplin kerja (X1) dan Pelatihan (X2), terhadap kinerja karyawan (Y) secara bersama-sama.

\section{Tabel 21. Hasil uji simultan}


a. Dependent Variable: TOTALLY

b. Predictors: (Constant), TOTALX2, TOTALX1

Sumber: Data diolah SPSS25

Berdasarkan pengujian, diperoleh $\mathrm{f}$ hitung sebesar (10.916) dan $\mathrm{f}$ tabel $(3,49)$ dengan menggunakan $\alpha=(0,05)$, hal ini menunjukkan bahwa nilai $\mathrm{F}$ hitung $>\mathrm{F}$ tabel dengan tingkat signifikan sebesar 0,01, maka sesuai dengan ketentuan tingkat signifikan 5\% maka dapat disimpulkan bahwa variabel Disiplin kerja dan Pelatihan secara bersama-sama berpengaruh signifikan terhadap variabel Kinerja pada PT. Kumala Motor Sejahtera Kota Palopo. Dengan demikian hipotesis pertama dinyatakan diterima.

\section{b. Uji t (parsial)}

Uji ini digunakan untuk mengetahui apakah masing-masing variabel bebasnya secara sendiri-sendiri berpengaruh signifikan terhadap variabel terikatnya dilihat pada pernyataan berikut:

1. Apabila signifikansi $\mathrm{Thitung}>\mathrm{T}_{\mathrm{tabel}}$ dan probabilitas $<0,05$, maka dikatakan signifikan atau hipotesis diterima.

2. Apabila signifikansi Thitung $<$ tabel dan probabilitas $>0,05$, maka dikatakan signifikan atau hipotesis ditolak.

\section{Tabel 22. Hasil uji parsial}

\begin{tabular}{|c|c|c|c|c|c|}
\hline & & Co & ficients $^{a}$ & & \\
\hline \multirow[b]{2}{*}{ Model } & \multicolumn{2}{|c|}{ Unstandardized Coefficients } & \multirow{2}{*}{$\begin{array}{c}\text { Standardized } \\
\text { Coefficients } \\
\text { Beta }\end{array}$} & \multirow[b]{2}{*}{$\mathrm{T}$} & \multirow[b]{2}{*}{ Sig } \\
\hline & B & Std. Error & & & \\
\hline $\begin{array}{rr}1 & \text { (Constant) } \\
\text { TOTALX1 } \\
\text { TOTALX2 }\end{array}$ & $\begin{array}{l}6.246 \\
0.756 \\
0.066\end{array}$ & $\begin{array}{l}8.113 \\
0.117 \\
0.115\end{array}$ & $\begin{array}{l}0.679 \\
0.070\end{array}$ & $\begin{array}{l}0.770 \\
4.266 \\
0.526\end{array}$ & $\begin{array}{l}0.540 \\
0.000 \\
0.675\end{array}$ \\
\hline
\end{tabular}

Sumber: Data diolah SPSS25

Berdasarkan hasil analisis data dengan menggunakan program SPSS pada tabel 22. Maka dapat disimpulkan bahwa :

1. Nilai Thitung (4.266) $>$ Ttabel (2.086) dan signifikansi sebesar $0.000<0.005$, maka dapat disimpulkan bahwa disiplin kerja (X1) secara parsial berpengaruh signifikan terhadap kinerja karyawan pada PT. Kumala Motor Sejahtera Kota Palopo.

2. Nilai Thitung $(0.526)<T_{\text {tabel }}(2.086)$ dan signifikan sebesar $0.675>0.005$, maka dapat disimpulkan bahwa pelatihan $\left(\mathrm{X}_{2}\right)$ secara parsial tidak berpengaruh 
signifikan terhadap kinerja karyawan Pada PT. Kumala Motor Sejahtera Kota Palopo.

Berdasarkan analisis regresi linear berganda untuk menganalisis pengaruh Disiplin kerja dan Pelatihan Terhadap Kinerja Karyawan Pada PT. Kumala Motor Sejahtera Kota Palopo, persamaan regresi dapat dijelaskan sebagai berikut:

$$
\mathrm{Y}=6.246+0.756 \mathrm{X}_{1}+0.066 \mathrm{X}_{2}+\mathrm{e}
$$

1. Konstanta sebesar 6.246 artinya jika $\mathrm{x}$ nilainya 0 , maka kinerja karyawan nilainya sebesar 6.246 .

2. Koefisien regresi variabel Disiplin Kerja (X1), sebesar 0.756 artinya jika Disiplin Kerja mengalami kenaikan 1 satuan, maka Kinerja Karyawan (Y) akan mengalami peningkatan sebesar 0.756 . koefisien bernilai positif antara Disiplin kerja dengan Kinerja Karyawan maka semakin tinggi Disiplin Kerja maka Kinerja Karyawan pada PT. Kumala Motor Sejahtera Kota Palopo akan semakin Meningkat.

3. Koefisien regresi variabel Pelatihan (X2) sebesar 0.066 artinya jika pelatihan mengalami penurunan 1 satuan, maka kinerja karyawan (Y) akan mengalami penurunan sebesar 0.066. koefisien bernilai negatif antara pelatihan dengan kinerja karyawan maka semakin menurun Kinerja Karyawan pada PT. Kumala Motor Sejahtera Kota Palopo.

\section{c. Uji koefisien determinasi $\left(\mathbf{R}^{2}\right)$}

Uji determinasi digunakan untuk mengetahui sumbangan pengaruh variabel independen terhadap variabel dependen. Koefisien ini menunjukkan seberapa besar persentase variasi variabel independen yang digunakan dalam model mampu menjelaskan variasi variabel dependen. Hasil dari perhitungan software SPSS diperoleh nilai $\mathrm{R}^{2}=0,522$ yang berarti bahwa sebesar 52,2\% kinerja karyawan pada PT. Kumala Motor Sejahtera Kota Palopo dapat dijelaskan oleh variabel Disiplin Kerja dan Pelatihan, sedangkan sisanya $(100 \%$ - 52,2 = 47,8\%) dipengaruhi oleh variabel lain diluar model yang diteliti. Nilai koefisien determinasi dapat dilihat pada tabel Model summary.

\subsection{Pembahasan}

Berdasarkan hasil penelitian yang dilakukan, diperoleh bahwa variabel Disiplin Kerja dan Pelatihan secara Bersama-sama berpengaruh terhadap kinerja karyawan. Hal ini menandakan bahwa apabila Disiplin Kerja dan Pelatihan karyawan kurang baik maka akan mempengaruhi Kinerja Karyawan itu sendiri, begitupun sebaliknya jika karyawan memiliki Disiplin Kerja Dan Pelatihan yang 
tinggi tentunya kinerjanya akan baik pula. Ini dilihat dari nilai standar, maka dapat disimpulkan bahwa variabel disiplin kerja dan pelatihan secara bersama-sama berpengaruh terhadap variabel kinerja karyawan pada PT. Kumala Motor Sejahtera Kota Palopo. Dimana hal ini selaras dengan penelitian yang dilakukan oleh Devi (2013). Dengan judul Pengaruh Motivasi dan Disiplin Kerja Terhadap Kinerja Pegawai Pada Kantor Dinas Pendapatan Daerah Provinsi Sumatera Utara UPTD. Metode analisis data menggunakan metode deskriptif dan metode kuantitatif yaitu dengan analisis regresi linear berganda yang digunakan untuk mengukur pengaruh Motivasi dan Disiplin Kerja Terhadap Kinerja Pegawai Pada Kantor Dinas Pendapatan Daerah Provinsi Sumatera Utara UPTD Binjai. Berdasarkan uji F diperoleh hasil F-hitung lebih besar dari pada F-tabel Motivasi Pegawai dan Disiplin Kerja Pegawai Bersama-sama berpengaruh positif terhadap kinerja pegawai. Berdasarkan Uji T Motivasi berpengaruh secara positif dan signifikan terhadap kinerja pegawai. Disiplin kerja adalah variabel yang dominan mempengaruhi kinerja peagawai pada kantor UPTD. Binjai. Melalui pengujian koefisien Determinasi diperoleh adjusted $\mathrm{R}$ Square Kinerja pegawai dapat dijelaskan oleh variabel motivasi dan disiplin kerja, sedangkan variabel kinerja dapat dijelaskan oleh variabel lainnya yang tidak diteliti dalam penelitian ini.

Dari hasil penelitian ini diperoleh bahwa variabel Disiplin kerja berpengaruh paling dominan terhadap Kinerja Karyawan pada PT. Kumala Motor Sejahtera Kota Palopo yang dilihat dari hasil uji t variabel Disiplin Kerja berdasarkan tabel Cofficients dapat dijelaskan bahwa nilai Thitung lebih besar dari Ttabel dengan demikian variabel disiplin kerja memiliki pengaruh signifikan terhadap variabel kinerja. Sementara variabel pelatihan nilai Thitung lebih kecil dari Ttabel yang berarti variabel pelatihan berpengaruh tidak signifikan terhadap kinerja karyawan. Hal ini sesuai juga dengan penelitian Devi (2013), Berdasarkan Uji T Motivasi berpengaruh secara positif dan tidak signifikan terhadap kinerja pegawai. Disiplin kerja adalah variabel yang dominan mempengaruhi kinerja peagawai pada kantor UPTD. Binjai. Kemudian penelitian lainnya yang dilakukan oleh Ayer, dkk (2016) dalam penelitian ini berjudul pengaruh motivasi dan disiplin kerja terhadap kinerja pegawai pada dinas pertanian kabupaten supiori, dalam penelitiannya ini bertujuan 
untuk mengetahui dan menganalisis apakah terdapat pengaruh motivasi dan disiplin kerja pegawai di Dinas Pertanian Kabupaten Supiori. Penelitian ini dikategorikan sebagai penelitian kausal asosiatifpendekatan kuanlitatif dengan instrument berupa kuesioner. Populasi dalam penelitian ini adalah seluruh pegawai Dinas Pertanian Kabupaten Supiori Sebanyak 80 orang. Teknik pengambilan sampling jenuh atau sensus, sampel dalam penelitian ini adalah dengan mengambil populasi sebanyak 80 orang. Data yang digunakan dalam penelitian ini adalah data primer yang diperoleh melalui kuesioner dan data sekunder yang diperoleh instansi jurnal terkait untuk mendukung penelitian ini. Uji validitas instrument menggunakan rumus correlation bivariate berganda digunakan untuk uji hipotesis penelitian ini. Hasil penelitian menunjukkan bahwa variabel motivasi berpengaruh positif dan signifikan terhadap kinerja pegawai Dinas Pertanian Kabupaten Supiori. Variabel Disiplin kerja berpengaruh positif dan signifikan terhadap pegawai Dinas Pertanian Kabupaten. Berdasarkan hasil uji kedua variabel independen yang diuji secara individual yang paling dominan dalam mempengaruhi kinerja pegawai di Dinas Pertanian Kabupaten Supiori adalah variabel disiplin kerja. Maka dapat disimpulkan bahwa pada penelitian ini variabel Disiplin kerja secara parsial merupakan faktor yang berpengaruh nyata terhadap kinerja.

Dari hasil penelitian berdasarkan analisis regresi berganda diketahui bahwa variabel Disiplin Kerja berpengaruh signifikan terhadap Kinerja Karyawan Sedangkan variabel Pelatihan berpengaruh positif dan tidak signifikan terhadap Kinerja Karyawan. Dari hasil ini tidak selaras dengan penelitian yang dilakukan oleh sanjaya (2015). Dalam penelitiannya yang berjudul pengaruh disiplin kerja dan motivasi kerja terhadap kinerja karyawan pada hotel Ros In Yogyakarta dari hasil penelitiannya menunjukkan bahwa, Tingkat variabel disiplin kerja karyawan hotel Ros In Yogyakarta dalam Kategori sedang. Motivasi kerja karyawan Hotel Ros In Yogyakarta dalam kategori sedang, dan kinerja karyawan Hotel Ros In Yogyakarta dalam kategori sedang, variabel Disiplin Kerja berpengaruh positif dan signifikan terhadap kinerja karyawan Hotel Ros In Yogyakarta. Variabel Motivasi kerja berpengaruh positif dan signifikan terhadap kinerja karyawan Hotel Ros In Yogyakarta, dan disiplin kerja dan motivasi kerja berpengaruh positif dan 
signifikan terhadap kinerja karyawan Hotel Ros In Yogyakarta. Dan juga tidak selaras dengan penelitian yang dilakukan oleh Annisa (2014) yang berjudul pengaruh motivasi dan disiplin kerja terhadap kinerja pegawai pada PT.Telekomunikasi Indonesia, Tbk Wilayah Telkom Pekalongan. Dari hasil penelitiannya menunjukkan bahwa terdapat pengaruh positif dan signifikan antara motivasi kerja terhadap kinerja karyawan, Dengan demikian berarti bahwa hipotesis yang menyatakan bahwa motivasi kerja memiliki pengaruh terhadap kinerja karyawan dapat diterima. Tidak terdapat pengaruh yang signifikan antara disiplin kerja terhadap kinerja karyawan,dan Terdapat pengaruh yang signifikan antara variabel motivasi dan disiplin kerja secara simultan terhadap kinerja karyawan PT. Telekomunikasi Indonesia Tbk. Witel Pekalongan.

Menurut Singodimedjo dalam Sutrisno (2016:86), bahwa disiplin adalah sikap kesediaan dan kerelaan seseorang untuk mematuhi dan menaati norma-norma peraturan yang berlaku diperusahaan

Menurut Wibowo (2014:370) pelatihan (training) merupakan investasi organisasi yang penting dalam sumber daya manusia. Pelatihan, melibatkan segenap sumber daya manusia untuk mendapatkan pengetahuan dan keterampilan pembelajaran sehingga mereka segera akan dapat menggunakannya dalam pekerjaan. pada dasarnya, pelatihan diperlukan karena adanya kesenjangan antara keterampilan pekerjaan sekarang dengan keterampilan yang dibutuhkan untuk menempati posisi baru.

Menurut Sutrisno dalam Catio (2020:21), Kinerja adalah hasil kerja yang telah dicapai sesorang dari tingkah laku kerjanya dalam melaksanakan aktifitas kerja.

\section{Kesimpulan}

Berdasarkan hasil analisis dan pembahasan yang telah dikemukakan pada bab sebelumnya, maka dapat ditarik kesimpulan sebagai berikut:

1. Disiplin kerja dan pelatihan secara simultan berpengaruh signifikan terhadap kinerja karyawan pada PT. Kumala Motor Sejahtera Kota Palopo.

2. Disiplin kerja berpengaruh signifikan terhadap kinerja karyawan pada PT. Kumala Motor Sejahtera Kota Palopo. 
3. Variabel Pelatihan berpengaruh tidak signifikan terhadap kinerja karyawan pada PT. Kumala Motor Sejahtera Kota Palopo.

\section{Daftar Pustaka}

Amdin, A.M. (2018). Pengaruh Pelatihan Terhadap Kinerja Karyawan pada PT. Pegadaian Cabang Palopo. Skiripsi Sumber Daya Manusia. Universitas Andi Djemma Palopo

Annisa. (2014). Pengaruh Motivasi dan Disiplin Kerja Terhadap Kinerja Pegawai pada PT. Telekomunikasi Indonesia, Tbk Wilayah Telkom Pekalongan [Skripsi]. Semarang (ID): Universitas Diponegoro Semarang.

Anyer, Pengamanan. Rori Y. (2016). Pengaruh Motivasi dan Disiplin Kerja Terhadap Kinerja Pegawai pada Dinas Pertanian Kabupaten Supiori. Jurnal Ekonomi. 12(3): 27-46

Asraul. (2017). Pengaruh Kedisiplinan dan Etika Karyawan Terhadap Produktivitas Kerja Pada Rabbids Coffee and Breakfast Kota Palopo. Skripsi Manajemen Sumber Daya Manusia . Universitas Andi djemma Palopo

Astuti, Prayogi. (2018). Pengaruh Kepemimpinan dan Prestasi Karyawan Terhadap Kinerja Karyawan Pada PT. Karya Hevea Indonesia Afdeling Hevea Dolok Masihul. Jurnal Maganemen dan Business(NCMAB). Universitas Muhammadiyah Sumatera Utara.

Benny, I.M.P dan Dwirandra, A.A.N.B. (2016). Kemampuan Opini Audit Tahun Sebelumnya Memoderasi Pengaruh Profitabilitas, Leverage, Likuiditas Pada "Opini Audit Going Concern". E-Jurnal Akuntansi Universitas Udayana 14 (2): 835-861.

Cation, Sunarsi. (2020). Analisa Pengaruh Kompensasi, Disiplin kerja dan Motivasi Terhadap Guru (SMK Sasmita Jaya 1 Pamulang Kota Tangerang Selatan). Jurnal Penelitian Pendidikan dan Ekonomi. Universitas Pamulang Tangerang Selatan. Vol. 17 (02)

Dessler, Gary. (2015). Manajemen Sumber Daya Manusia. Jakarta: Salemba Empat.

Devi A. (2013). Pengaruh Motivasi dan Disiplin Kerja Terhadap Kinerja Pegawai pada Kantor Dinas Pendapatan Daerah Provinsi Sumatera Utara UPT binjai [Skripsi]. Medan (ID). Universitas Sumatera Utara

Firmansyah, dkk. (2020). Pengaruh Motivasi Individual dan Gaya Kepemimpinan Terhadap Kinerja Pegawai Dikementerian Pemberdayagunaan Apatur Negara dan Reformasi Birokrasi. Jurnal Manajemen Bisnis dan Publik (JMBP), 1 ( 1).

Fitriani. (2020). Pengaruh Pelatihan dan Disiplin kerja Karyawan Pada PDAM Tirtanadi Provinsi Sumatera Utara. Skripsi Ekonomi dan Bisnis. Universitas Muhammadiyah Sumatera Utara.

Ghozali, I. 2011. Aplikasi Analisis Multivarative Dengan Program SPSS, cetakan Kelima, BP Universitas Diponegoro, Semarang

Ghozali, I. 2015. Aplikasi Analisis multivariate dengan program IMB SPSS 23. Semarang: Badan Penerbit Univesitas Diponegoro. 
Ginting. 2018. Pengaruh Pengawasan dan Komunikasi Terhadap Disiplin Kerja Karyawan Pada PT. Zhafira Tetap Jaya Medan. Jurnal Ekonomi dan Bisnis. Universitas Medan Area Medan

Hamali. 2016. Pemahaman Sumber Daya Manusia. Yogyakarta: CAPS

Hasriyanti. 2019. Pengaruh Pelatihan dan Disiplin Kerja Terhadap Kinerja

Karyawan Pada Dinas Penanaman Modal Dan Pelayanan Terpadu Satu

Pintu Kota Palopo. Skripsi Manajemen sumber Daya Manusia.

Universitas Andi Djemma Palopo.

Kartika \& Djastuti. 2017. Pengaruh Pelatihan dan Disiplin Kerja Terhadap

Kinerja Karyawan dengan Kepuasan Sebagai Variabel Intervening. Jurnal Manajemen. Universitas Diponegoro. Vol. 6(4)

Kartika, P., \& Khaerana, K. (2019). PENGARUH KOMPETENSI DAN KOMPENSASI TERHADAP PRODUKTIVITAS KERJA KARYAWAN PADA PT. BANK RAKYAT INDONESIA KANTOR CABANG PALOPO. JEMMA (Journal of Economic, Management and Accounting), 2(2), 38-44.

Kasmir. 2016. Manajemen Sumber Daya Manusia (Teori dan Praktik). Depok: PT Rajagrafindo Persada.

Mangkunegara, AP. 2010. Manajemen Sumber Daya Manusia Perusahaan. Bandung: Remaja Rosdakarya.

Khaerana, K., \& Olfiyandari, O. (2019). PENGARUH TINGKAT PENDIDIKAN TERHADAP KUALITAS KERJA PEGAWAI PADA KANTOR URUSAN AGAMA KECAMATAN LAMASI TIMUR. JEMMA (Journal of Economic, Management and Accounting), 2(1), 5968.

Pareraway, dkk. 2018. Pengaruh Lingkungan Kerja, Pelatihan, dan Pemberdayaan Sumber Daya Manusia Terhadap Kepuasan Kerja Karyawan PT. PLN (Persero) Wilayah Suluhengo. Jurnal Ekonomi Bisnis. Universitas Samratulangi.

Permatasari, dkk. 2015. Pengaruh Disiplin Kerja dan Motivasi Kerja Terhadap Prestasi Kerja Karyawan (Studi Pada PT. Gunung Ringgit Malang). Jurnal Ilmu Administrasi. Universitas Brawijaya

Pulungan,K.K. 2018. Pengaruh Disiplin Kerja dan Pelatihan Kerja Terhadap Kinerja Karyawan Pada PT. Motivindo Berkah Sejahtera Jakarta.Skripsi Ekonomi dan Bisnis. Universitas Medan.

Pratama, Mukzam. 2018. Pengaruh Metode Pelatihan dan Materi Pelatihan Terhadap Kemampuan Kerja dan Kinerja Karyawan. Jurnal Administrasi Bisnis. Vol. 62(1).

Robbins, Stephen P \& Judge, Timothy A. 2013. Organizationa Behavior Edition 15. New Jersey: Pearson Education

Sanjaya R. 2015. Pengaruh Disiplin Kerja dan Motivasi Kerja Terhadap Kinerja Karyawan pada Hotel Ros In Yogyakarta [Skripsi]. Bogor (ID): Universitas Negeri Yogyakarta

Sugiyono. 2016. Metode Penelitian Kuantitatif, Kualitatif dan R\&D. Bandung: Alfabeta.

Suparyadi. 2015. Manajemen Sumber Daya Manusia, Edisi 1. Yogyakarya: Andi Offiset. 
Suwondo, Susanto. 2015. Hubungan Lingkungan Kerja, Disiplin Kerja, Dan Kinerja Karyawan. Jurnal Manajemen. Universitas Kristen Petra Surabaya. Vol. 17(2) 135-144

Suti, M., Syahdi, M. Z., \& Didiharyono, D. (2020). Tata Kelola Perguruan Tinggi dalam Era Teknologi Informasi dan Digitalisasi. JEMMA (Journal of Economic, Management and Accounting), 3(2), 203-214.

Tanjung. 2015. Pengaruh Disiplin Kerja dan Motivasi Kerja Terhadap Prestasi Kerja Pegawai Pada Dinas Sosial dan Tenaga Kerja Kota Medan. Jurnal Ilmiah Manajemen dan Bisnis. Universitas Muhammadiyah Sumatera Utara. Vol. 15(01) 1693-7619.

Tuhumena, dkk. 2017. Pengaruh Pelatihan dan Motivasi Kerja Terhadap Kinerja Karyawan Pada PT. Pegadaian (persero) Kantor wilayah V manado. Jurnal Ekonomi dan Bisnis. Universitas Sam Ratulangi Manado. Vol. 5(2): 2124-2133

Wibowo. 2014. Manajemen Kinerja, Edisi Keempat. Jakarta: Rajawali Pers

Zamora. 2019. Lingkungan Kerja, Disiplin Kerja, Stress Kerja, Kinerja Karyawan. Jurnal Manajemen Ekonomi. Universitas Riau Kepulauan. Vol. 7(2). 